\title{
MENCARI SISTEM PENYELESAIAN SENGKETA KONSUMEN YANG IDEAL DALAM RANGKA MENINGKATKAN PERLINDUNGAN TERHADAP KONSUMEN
}

\author{
Janus Sidabalok \\ Fakultas Hukum Universitas Katolik Santo Thomas, Medan, Indonesia \\ Email: janus.sidabalok@gmail.com
}

\begin{abstract}
ABSTRAK
Tujuan penelitian ini adalah untuk menemukan sistem penyelesaian sengketa konsumen yang ideal dalam rangka memberi perlindungan kepada konsumen, dengan mengkaji ketentuan-ketentuan penyelesaian sengketa konsumen dan ketentuan-ketentuan tentang organisasi dan tata kerja Badan Penyelesaian Sengketa Konsumen (BPSK), yang terdapat di dalam Undang-Undang Nomor 8 Tahun 1999 tentang Perlindungan Konsumen (UUPK), dihubungkan dengan ketentuan perundang-undangan lain tentang penyelesaian sengketa, pendapat para ahli, serta sejumlah putusan-putusan BPSK. Kajian dimaksudkan untuk menemukan kekurangan atau kelemahan dalam pengaturannya, yang dipandang memengaruhi penyelesaian sengeketa yang ideal: efektif, cepat, murah, dan adil.

Hasil penelitian menunjukkan bahwa terdapat sejumah kelemahan di dalam ketentuan tentang penyelesaian sengketa sebagaimana terdapat pada UUPK, demikian juga dengan ketentuan yang menyangkut BPSK. Sikap dan pandangan lembaga peradilan konvensional dalam memandang putusan BPSK pun turut memengaruhi efektivitas BPSK sebagai alternatif penyelesaian sengketa konsumen. Disarankan beberapa ketentuan tentang penyelesaian sengketa konsumen dan BPSK yang terdapat di dalam UUPK perlu direvisi.
\end{abstract}

Kata kunci: sengketa konsumen, penyelesaian sengketa ideal, BPSK.

\begin{abstract}
The purpose of this research is to find the ideal consumer dispute resolution system in order to provide protection to consumers, by examining the provisions for consumer dispute resolution and provisions regarding the organization and work procedures of the Consumer Dispute Resolution Agency (BPSK), which are contained in Act on Consumer Protection Number 8 of 1999 (UUPK), is linked to other statutory provisions regarding dispute resolution, expert opinion, as well as a number of BPSK decisions. The study is intended to find shortcomings or weaknesses in its regulation, which are seen as influencing the ideal settlement of deliberations: effective, fast, cheap, and fair. The results show that there are a number of weaknesses in the provisions concerning dispute resolution as contained in the UUPK, as well as the provisions concerning BPSK. The attitudes and views of conventional judicial institutions in viewing the BPSK decision also influence the effectiveness of BPSK as an alternative to consumer dispute resolution. It is suggested that several provisions regarding consumer dispute resolution and BPSK contained in the UUPK need to be revised.
\end{abstract}

Keywords: consumer disputes, ideal dispute resolution, BPSK.

Mencari Sistem Penyelesaian Sengketa Konsumen Yang Ideal Dalam Rangka Meningkatkan Perlindungan Terhadap Konsumen

Oleh : Janus Sidabalok, S.H., M.Hum 


\section{A. PENDAhULUAN}

Hukum merupakan sebuah sistem, sebuah kumpulan atau kesatuan dari beberapa bagian yang menyebabkan hukum itu dapat mencapai tujuannya. Sistem hukum terdiri dari bagian-bagian yang saling berkaitan dan menunjang satu sama lain. ${ }^{1}$ Keberhasilan penegakan hukum terkait dengan sistem hukum yang terdiri dari berbagai unsur atau komponen hukum yang mampu memberi perlindungan secara sistematis, seperti masyarakat hukum, budaya hukum, filsafat hukum, ilmu hukum, konsep hukum, pembentukan hukum, penerapan hukum dan evaluasi hukum $^{2}$ atau menurut Laurence $M$ Friedman, menyangkut substansi hukum (legal substance), struktur hukum (legal structure), dan budaya hukum (legal culture). ${ }^{3}$

Sistem hukum perlindungan konsumen sebagai salah satu bagian dari keseluruhan sistem hukum nasional menghendaki adanya perlindungan hukum yang memadai bagi konsumen, sehingga hak-hak konsumen terlindungi dengan baik dan dengan demikian tercapailah masyarakat yang sejahtera sebagaimana dimaksud pada tujuan pembangunan nasional.

Sistem hukum perlindungan konsumen yang dimaksud meliputiketersediaan peraturan perundang-undangan konsumen yang memadai, berjalannya penegakan hukum melalui aparatur penegak hukum, adanya lembaga penegakan hukum yang bekerja dengan baik, dan terciptanya budaya hukum di kalangan masyarakat konsumen maupun pelaku

1 Sudikno Mertokusumo, Mengenal Hukum, Yogyakarta: Liberty, 1986, hlm.102.

2 Lili Rasjidi dan Ida Bagus Wyasa Putra, Hukum Sebagai Suatu Sistem, Jakarta: Fikahati Aneska, 2012, hlm.152-167.

3 Ade Maman Suherman, Pengantar Perbandingan Sistem Hukum, Jakarta,: RajaGrafindo Persada, 2004, hlm. 11. usaha yang mendukung penegakan hukum perlindungan konsumen itu sendiri.

Melalui Undang-Undang Nomor 8 Tahun 1999 tentang Perlindungan Konsumen (UUPK) diperolehlah satu unsur dari sistem perlindungan konsumen di Indonesia, yaitu penyelesaian sengketa konsumen. Di dalam UUPK ini dibuka peluang untuk menyelesaikan sengketa konsumen di luar pengadilan. Salah satu di antaranya ialah penyelesaian sengketa konsumen melalui Badan Penyelesaian Sengketa Konsumen (BPSK) sebuah lembaga baru yang dibentuk berdasarkan undang-undang ini.

Melalui pembentukan BPSK, makin lengkaplah unsur yang dimiliki, sebab konsumen yang merasa dirugikan haknya dapat menuntut atau menggugat pihak pelaku usaha yang diduga menimbulkan kerugian ke BPSK. Artinya konsumen mempunyai alternatif lain dalam penyelesaian sengketa yang dihadapinya.

Sebagai lembaga yang relatif baru, BPSK tidak lantas dikenal oleh masyarakat dan dijadikan sebagai pilihan dalam menyelesaian sengketa. Demikian juga dengan hubungan antara BPSK dengan lembaga peradilan umum memengaruhi eksistensi BPSK serta efektivitasnya.

Selanjutnya ketentuan penyelesaian sengketa menurut UUPK ini diharapkan memberi sumbangan terhadap perbaikan iklim usaha sehingga menjadi lebih sehat, di mana antara pelaku usaha dengan konsumen terpelihara hubungan yang baik dan saling menguntungkan.

Dalam kaitan itulah dipermasalahkan: Apakah pengaturan penyelesaian sengketa konsumen dan pembentukan BPSK di dalam UndangUndang Nomor 8 Tahun 1999 tentang Perlindungan Konsumen telah mampu

Mencari Sistem Penyelesaian Sengketa Konsumen Yang Ideal Dalam Rangka Meningkatkan 
melahirkan sebuah sistem penyelesaian sengketa konsumen yang ideal bagi konsumen sehubungan dengan upaya untuk meningkatkan kesejahteraan masyarakat Indonesia? Ukuran ideal dalam hal ini adalah penyelesaian yang efektif, cepat, murah, dan adil dan didukung oleh aturan yang lengkap.

Selaras dengan permasalahan tersebut, penelitian ini bertujuan untuk mencari dan menemukan sistem penyelesaian sengketa konsumen yang ideal yang dapat memberi perlindungan yang baik kepada konsumen. Dalam penelitian ini dikaji ketentuan tentang penyelesaian sengketa serta ketentuan tentang BPSK; untuk mengetahui kelemahan dan atau kekurangannya sehingga dapat dirumuskan ketentuan yang ideal.

Penelitian ini diharapkan memberi manfaat atau kegunaan dalam pemberian perlindungan hukum kepada konsumen khususnya sistem penyelesaian sengketa konsumen dalam rangka penegakan hukum konsumen, melalui upaya menemukan suatu sistem penyelesaian sengketa yang ideal, memadai, dan cocok bagi Indonesia. Dengan demikian hasil penelitian ini dapat dimanfaatkan oleh pemerintah, BPSK, maupun masyarakat.

\section{B. TINJAUAN PUSTAKA \\ 1. Perlindungan Konsumen}

Di dalam Pasal 1 angka 1 UUPK disebutkan: perlindungan konsumen adalah segala upaya yang menjamin adanya kepastian hukum untuk memberi perlindungan kepada konsumen. Dengan demikian perlindungan konsumen mempersoalkan jaminan atau kepastian tentang terpenuhinya hak-hak konsumen.

Perlindungan konsumen

mencakup perlindungan terhadap konsumen dalam memperoleh barang dan jasa, yang berawal dari tahap kegiatan untuk mendapatkan barang dan jasa, dan perlindungan dari akibatakibat pemakaian barang dan jasa itu.

Yang pertama masuk dalam cakupan tanggung jawab produk, yaitu tanggung jawab yang dibebankan kepada produsen-pelaku usaha karena barang yang diserahkan kepada konsumen itu mengandung cacat di dalamnya, sehingga menimbulkan kerugian bagi konsumen. ${ }^{4}$ Dalam kaitan ini, beberapa persoalan yang timbul menyangkut bahan baku, proses produksi, desain dan sebagainya yang berhubungan dengan menghasilkan produk.

Sedangkan yang kedua masuk dalam cakupan standar kontrak yang mempersoalkan syarat-syarat perjanjian yang diberlakukan oleh produsenpelaku usaha kepada konsumen pada waktu konsumen hendak mendapatkan barang atau jasa kebutuhannya. ${ }^{5}$

Menyimak pertimbangan atau konsiderans yang terdapat di dalam UUPK dapat dirumuskan sekurangkurangnya ada 6 (enam) alasan pokok mengapa konsumen perlu dilindungi:

1. Melindungi konsumen berarti melindungi seluruh warga negara,

2. menjaga kesinambungan pembangunan nasional,

3. menjamin sumber dana pembangunan,

4. menghindarkan konsumen dari dampak negatif penggunaan teknologi.

5. mencegah perilaku curang dari pelaku usaha,

6. meningkatkan pemberdayaan konsumen, khususnya penanaman kesadaran akan hak dan kewajibannya. ${ }^{6}$

\footnotetext{
4 Janus Sidabalok, Hukum Perlindungan Konsumen di Indonesia, Bandung, Citra Aditya Bakti, 2014, hlm.8

5 Loc Cit.

$6 \quad$ Ibid, hlm.23.
}

Mencari Sistem Penyelesaian Sengketa Konsumen Yang Ideal Dalam Rangka Meningkatkan Perlindungan Terhadap Konsumen

Oleh : Janus Sidabalok, S.H., M.Hum 
Oleh karena itu persoalan perlindungan konsumen adalah bagian dari persoalan pembangunan nasional.

\section{Sengketa Konsumen}

\section{a. Forum dan Cara Penyelesaian Sengketa}

Yang dimaksud dengan sengketa konsumen di sini adalah sengketa yang terjadi antara pelaku usaha dengan konsumen, sehubungan dengan transaksi konsumen. Sengketa konsumen dapat bersumber dari dua hal, yaitu karena Pelaku usaha tidak melaksanakan kewajiban hukumnya sebagaimana diatur di dalam undangundang, yang dikualifikasikan sebagai perbuatan melanggar hukum, dan karena Pelaku usaha atau konsumen tidak menaati isi perjanjian atau kontrak dikualifikasikan sebagai wanprestasi. ${ }^{7}$

Pada ketentuan tentang tanggung jawab pelaku usaha ditegaskan bahwa pelaku usaha bertanggungjawab atas kerusakan, pencemaran, dan atau kerugian konsumen akibat mengkonsumsi barang dan atau jasa yang dihasilkan dan atau diperdagangkan (Pasal 19 ayat (1) UUPK). Ketentuan ini berlaku sebagai aturan umum bagi pelaku usaha.

Sementara itu bagi pelaku usaha tertentu ditetapkan tanggungjawabnya sebagaimana diatur di dalam Pasal 20 UUPK untuk pelaku usaha periklanan, Pasal 21 UUPK untuk pelaku usaha yang bertindak sebagai importir, Pasal 24 UUPK untuk pelaku usaha yang bertindak sebagai penjual kepada pelaku usaha lain, Pasal 28 UUPK untuk pelaku yang memproduksi barang yang pemanfaatannya berkelanjutan, dan Pasal 26 UUPK untuk pelaku usaha perdagangan jasa. Pada Pasal 27 UUPK diatur pembebasan tanggung jawab dari

$7 \quad$ Ibid, hlm. 127 pelaku usaha yang memproduksi barang atas kerugian yang diderita konsumen.

Ketentuan tentang tanggung jawab pelaku usaha ini memberi petunjuk mengenai ruang lingkup sengketa konsumen, termasuk sengketa konsumen yang menjadi kompetensi BPSK.

Dari ketentun Pasal 45 - Pasal 48, jis Pasal 49 - Pasal 58, dan Pasal 19 Pasal 28 UUPK, diketahui bahwa tersedia tiga forum dan cara untuk menyelesaikan sengketa konsumen, yaitu:

a. Penyelesaian sengketa konsumen di luar pengadilan dengan tuntutan seketika melalui forum negosiasi, konsultasi, konsiliasi, mediasi, dan penilaian ahli;

b. Penyelesaian sengketa konsumen melalui BPSK; dan

c. Penyelesaian sengketa konsumen melalui pengadilan.

Dari tiga forum dan cara di atas, penyelesaian sengketa melalui tuntutan seketika wajib ditempuh pertama kali untuk memperoleh kesepakatan para pihak. Forum dan cara kedua dan ketiga adalah pilihan yang ditempuh setelah penyelesaian dengan cara kesepakatan gagal.

Forum BPSK atau pengadilan dipilih secara sukarela sebagaimana ditentukan pada Pasal 45 ayat (2) UUPK. Kalau sudah memilih untuk menempuh forum dan cara BPSK, penyelesaian melalui forum dan cara pengadilan tidak dapat lagi ditempuh sebagaimana ditentukan pada Pasal 45 ayat (4) UUPK.

Demikian halnya bahwa sengketa konsumen tidak dapat diajukan ke pengadilan dan di luar pengadilan sekaligus, misalnya salah satu pihak mengajukan gugatan ke BPSK dan juga ke pengadilan; atau pihak yang satu mengajukan ke BPSK sementara pihak lain mengajukan ke pengadilan.

Mencari Sistem Penyelesaian Sengketa Konsumen Yang Ideal Dalam Rangka Meningkatkan Perlindungan Terhadap Konsumen

Oleh : Janus Sidabalok, S.H., M.Hum 
Menurut Pasal 19 ayat (1) dan (3) UUPK ini, konsumen yang merasa dirugikan dapat menuntut secara langsung penggantian kerugian kepada produsen-pelaku usaha dan harus memberi tanggapan dan atau penyelesaian dalam jangka waktu 7 (tujuh) hari setelah transaksi berlangsung.

Cara yang dimaksud oleh Pasal 19 ayat (1) UUPK itu tidak jelas. Akan tetapi, dengan menyimak Pasal 19 ayat (3) UUPK, pastilah yang dimaksud bukan melalui suatu badan dengan acara pemeriksaan tertentu. Dengan penetapan jangka waktu 7 (tujuh) hari setelah tanggal transaksi sebagaimana disebut dalam Pasal 19 ayat (3) UUPK, maka dapat diduga bahwa penyelesaian sengketa yang dimaksudkan di sini bukanlah penyelesaian yang rumit dan melalui pemeriksaan mendalam terlebih dahulu, melainkan bentuk penyelesaian sederhana dan praktis yang ditempuh dengan jalan damai misalnya negosiasi, dan mediasi. (bdk. Pasal 47 UUPK).

Mengikuti ketentuan UndangUndang Nomor 30 Tahun 1999 tentang Arbitrase dan Alternatif Penyelesaian Sengketa, cara penyelesaian sengketa di luar pengadilan itu dapat berupa konsultasi, negosiasi, mediasi, konsiliasi, atau penilaian ahli.

Penyelesaian sengketa di luar pengadilan dilaksanakan untuk mencapai kesepakatan mengenai bentuk dan besarnya ganti kerugian dan atau mengenai tindakan tertentu untuk menjamin tidak akan terjadi kembali dapat berupa:1) pengembalian uang seharga pembelian barang dan atau jasa; 2) penggantian barang dan atau jasa sejenis atau setara nilainya; atau 3) perawatan kesehatan; atau 4) pemberian santunan yang sesuai.

\section{b. Penyelesaian Sengketa Konsumen melalui BPSK}

Penyelesaian sengketa melalui BPSK termasuk penyelesian sengketa di luar pengadilan, dan mirip dengan badan arbitrase. Badan ini merupakan badan hasil bentukan pemerintah, yang berkedudukan di ibu kota Daerah Tingkat II Kabupaten/ Kota (Pasal 49 ayat (1) UUPK).

BPSK adalah lembaga yang memeriksa dan memutus sengketa konsumen, yang bekerja seolah-olah sebagai sebuah pengadilan. Oleh karena itu, BPSK ini dapat disebut sebagai peradilan kuasi.

Mengikuti ketentuan Pasal 23 UUPK, penyelesaian sengketa konsumen melalui BPSK ini dapat ditempuh, yaitu jika penyelesaian secara damai di luar proses pengadilan tidak berhasil, baik karena produsen-pelaku usaha menolak atau tidak memberi tanggapan maupun jika tidak tercapai kesepakatan. Apabila penyelesaian dipilih melalui BPSK dan BPSK ini tidak berhasil menyelesaikan sengketa, maka sengketa masih dapat diserahkan ke pengadilan.

Mekanisme kerja BPSK dalam menerima, memeriksa, dan memutus sengketa, yang dapat dibagi dalam tiga tahapan kegiatan, yaitu tahap pemasukan gugatan/ permohonan, tahap pemeriksaan, dan putusan.

Dalam Penjelasan Pasal 45 ayat

(2) UUPK pada pokoknya dikatakan:

1. Penyelesaian sengketa konsumen (di luar pengadilan) tidak menutup kemungkinan penyelesaian damai oleh para pihak yang bersengketa.

2. Pada setiap tahap diusahakan untuk menggunakan penyelesaian damai oleh kedua belah pihak yang bersengketa.

3. Penyelesaian secara damai adalah penyelesaian yang dilakukan oleh kedua belah pihak yang

Mencari Sistem Penyelesaian Sengketa Konsumen Yang Ideal Dalam Rangka Meningkatkan Perlindungan Terhadap Konsumen

Oleh : Janus Sidabalok, S.H., M.Hum 
bersengketa (pelaku usaha dan konsumen) tanpa melalui peradilan atau BPSK dan tidak bertentangan dengan undangundang ini.

Jadi menurut Pasal 47 UUPK tersebut penyelesaian sengketa konsumen di luar pengadilan ini bertujuan untuk mencapai kesepakatan atau perdamaian.

Negosiator, konsultan, konsiliator, mediator, maupun arbiter berusaha mencapai kesepakatan atau tidak akan terulang kembali kerugian yang diderita oleh konsumen (Pasal 47 UUPK). Dengan cara ini dimaksudkan supaya persoalan antara konsumen dan produsen-pelaku usaha dapat segera ditemukan jalan penyelesaian. Pada penyelesaian sengketa seperti ini, kerugian yang dapat dituntut, sesuai dengan Pasal 19 ayat (1) UUPK terdiri dari kerugian karena kerusakan, pencemaran, dan kerugian konsumen akibat dari mengonsumsi atau memakai barang dan atau jasa.

\section{METODE PENELITIAN}

Penelitian ini mengambil norma hukum dan aturan-aturan hukum sebagai objek kajiannya. Sifatnya adalah penelitian normatif yaitu penelitian yang bertujuan mencari kaidah hukum yang terdapat di dalam peraturan perundang-undangan.

Metode pendekatannya adalah pendekatan perundang-undangan (statute approach) yaitu menelaah peraturan perundang-undangan yang berkaitan dengan pokok masalah.

Data yang digunakan untuk penelitian ini adalah data sekunder yang bersumber dari bahan hukum primer yaitu bahan hukum yang mengikat, bahan hukum yang autoritatif, mempunyai otoritas ${ }^{8}$, berupa peraturan perundang-undangan.

Peraturan perundang-undangan yang dijadikan bahan dan sumber data dalam penelitian ini yaitu:

a. ketentuan tentang Sengketa Konsumen dan Penyelesaian Sengketa Konsumen yang terdapat di dalam UUPK,

b. ketentuan tentang Badan Penyelesaian Sengketa Konsumen (BPSK) yang terdapat di dalam UUPK,

c. ketentuan mengenai penyeleaian sengketa dan mengenai BPSK yang terdapat pada peraturanperaturan lain, dapat berupa peraturan pemerintah peraturan menteri, peraturan BPSK, dan sebagainya.

d. ketentuan tentang sengketa dan penyelesaian sengketa sebagaimana terdapat di dalam $\mathrm{KUH}$ Perdata dan HIR/RBg.

Digunakan juga bahan hukum sekunder berupa pandangan para ahli yang diperoleh dari buku-buku referensi, artikel di jurnaal, dan tulisan lain, dan bahan hukum tertier berupa kamus hukum, ensiklopedia dan lainlain yang relevan dengan topik penelitian ini.

Dalam penelitian hukum normatif pengolahan data diartikan sebagai kegiatan sistematiasi terhadap bahanbahan hukum, yang berarti bahwa ada pengklasifikasian data unttuk kepentingan analisis dan konstruksi. ${ }^{9}$

Oleh karena hukum menghendaki dan mengatur bagaimana yang seharusnya (das sollen), maka sifat preskriftif dari hukum menghendaki agar analisis diarahkan untuk memberi argumentasi mengenai benar atau

\footnotetext{
8 Marzuki, 2014, Penelitian Hukum, Jakarta: Prenamedia Group, hlm.181.

9 Sukanto, 2012, Pengantar Penelitian Hukum, Jakarta: UI Press, hlm.251.
}

Mencari Sistem Penyelesaian Sengketa Konsumen Yang Ideal Dalam Rangka Meningkatkan Perlindungan Terhadap Konsumen 
salahnya gambaran yang diperoleh dan kemudian menentukan apa yang seharusnya menurut hukum. ${ }^{10}$

Data yang dikumpulkan dianalisis secara normatif, logis dan sistematis. Selanjutnya menggunakan metode komparatif (perbandingan) yaitu membandingkan materi pengaturan tentang penyelesaian pengketa dan materi pengaturan tentang BPSK, di dalam UUPK, dan peraturan perundangundangan lain yaitu KUH Perdata dan $\mathrm{HIR} / \mathrm{Rbg}$.

\section{HASIL PENELITIAN DAN PEMBAHASAN \\ 1. HASIL PENELITIAN}

Di dalam penelitian ini dilakukan pengumpulan data mengenai 6 (enam) hal utama yang menjadi bagian dari pokok permasalahan penelitian ini untuk memperoleh gambaran tentang penyelesaian sengketa konsumen yang ideal, yaitu ketentuan undang-undang terkait dengan a. Tanggung jawab Pelaku Usaha; b. Forum dan cara penyelesian sengketa konsumen; c. Kelembagaan BPSK; d. Prosedur dan tata kerja BPSK; e. Perbandingan penyelesaian perkara di BPSK dengan Pengadilan Negeri/ Mahkamah Agung; dan f. Kompetensi BPSK.

Dengan ini diharapkan diperoleh gambaran tentang penyelesian sengketa konsumen, baik keunggulan maupun kelemahannya, sehingga melalui analisis dapat dicari altenatif lain yang lebih baik.

1. Ketentuan Undang-Undang terkait dengan Tanggung jawab Pelaku Usaha

Ketentuan tentang tanggung jawab Pelaku Usaha pada pokoknya menentukan sebagai berikut:

10 Fajar dan Achmad, 2015, Dualisme Penelitian Hukum Normatif dan Empiris, Yogyakarta: Pustaka Pelajar, hlm.183. a. Pelaku usaha bertangungjawab atas kerusakan, pencemaran, dan kerugian konsumen;

b. Pelaku usaha periklanan bertanggungjawab atas segala akibat dari iklan,

c. Pelaku usaha penjual barang tak habis pakai bertanggungjawab atas ketersediaan suku cadang,

d. Pelaku usaha penjual barang tak habis pakai bertanggungjawab atas jaminan atau garansi,

e. Pemberian ganti rugi dilaksanakan dalam tenggang waktu 7 (tujuh) hari setelah tanggal transaksi.

f. Jika pelaku usaha menolak dan atau tidak memberi tanggapan dan atau tidak memenuhi ganti rugi dapat

g. Gugatan dapat diajukan ke BPSK atau ke badan peradilan.

2. Ketentuan yang terkait dengan

Penyelesaian Sengketa Konsumen

Ketentuan tentang Penyelesaian Sengketa pada pokoknya menentukan sebagai berikut:

a. Setiap konsumen yang dirugikan dapat menggugat pelaku usaha melalui lembaga yang bertugas atau melalui peradilan.

b. Penyelesaian sengketa melalui pengadilan atau di luar pengadilan didasarkan pada pilihan para pihak.

c. Penyelesaian sengketa di luar pengadilan tidak menghilangkan tanggung jawab pidana.

d. Jika telah di pilih forum di luar pengadilan, tdak dapat diajukan ke pengadilan.

e. Gugatan melalui pengadilan hanya dapat dilakukan jika di luar pengadilan dinyatakan tidak berhasil.

f. Gugatan diajukan oleh seorang konsumen atau ahli warisnya; sekelompok konsumen, lembaga perlindungan konsumen swadaya

Mencari Sistem Penyelesaian Sengketa Konsumen Yang Ideal Dalam Rangka Meningkatkan 
masyarakat, atau pemerintah/ instansi terkait.

g. Penyelesaian sengketa konsumen di luar pengadilan diselenggarakan untuk mencapai kesepakatan mengenai bentuk dan besarnya ganti rugi.

h. Penyelesaian sengketa konsumen melalui pengadilan mengacu pada ketentuan tentang peradilan umum.

3. Ketentuan Undang-Undang terkait dengan Kelembagaan BPSK

Ketentuan tentang Organisasi dan Keanggotaan BPSK pada pokoknya sebagai berikut:

a. Pemerintah membentuk BPSK di daerah Kabupaten/ Kota untuk penyelesaian sengketa konsumen di luar pengadilan;

b. Anggota BPSK harus memenuhi sejumlah persyaratan.

Persyaratan menjadi anggota BPSK sebagaimana dimaksud dalam huruf $b$ di atas kemudian diatur di dalam Kepmenperindag Nomor 350/MPPP/ Kep/12/2001 tentang Pelaksanaan Tugas dan Wewenang Badan Penyelesaian Sengketa Konsumen:

a. Anggota BPSK terdiri dari unsur pemerintah, konsumen, dan pelaku usaha.

b. Setiap unsur diwakuli oleh minimal 3 orang dan maksimal 5 orang.

c. Anggota BPSK diangkat dan diberhentikan oleh menteri.

d. BPSK terdiri dari ketua, wakil ketua, dan anggota.

e. BPSK dibantu oleh sekretriat.

f. Sekretariat terdiri dari kepala sekretariat dan anggota.

g. Pengangkatan dan pemberhentian angota ditetapkan oleh presiden.

Sementara itu ketentuan tentang Tugas dan Wewenang BPSK adalah sebagai berikut: a. Melakukan penanganan dan penyelesaian sengketa; caranya mediasi, arbitrase, dan konsiliasi;

b. Memberikan konsultasi,

c. Memberi laporan kepada pemerintah,

d. Menerima pengaduan,

e. Melakukan pengwasan atas klausula baku,

f. Melalukan peneelitian dan pemeriksaan,

g. Memanggil pelaku usaha,

h. Memanggil dan menghadirkan saksi, saksi ahli dan setiap orang terkait,

i. Meminta bantuan penyidik,

j. Menapaatkan, meneliti, menilai surat, dokumen, atau alat bukti lain,

k. Memutuskan dan menetapkan,

1. Memberitahukan putusan,

m. Menjatuhkan sanksi administratif.

4. Ketentuan terkait dengan Posedur,

Tata kerja serta Putusan BPSK Prosedur dan tata kerja BPSK pada pokoknya adalah sebagai berikut.

a. BPSK mengangkat majelis,

b. Jumlah majelis adalah ganjil, minimal 3 orang dan maksimal 5 orang,

c. Putusan majelis adalah final dan mengikat,

d. BPSK wajib mengeluarkan putusan paling lama 21 hari kerja setelah gugatan diterima,

e. Para pihak dapat mengajukan keberatan paling lama 14 hari kerja setelah putusan diterima,

f. Jika tidak mengajukan keberatan, dianggap menerima putusan,

g. Pelaku usaha wajib menjalankan putusan,

h. Apabila putusan tidak dilaksanakan, BPSK menyerahkan putusan kepada penyidik,

i. Putusan BPSK merupakan bukti permulaan yang cukup bagi penyidik,

Mencari Sistem Penyelesaian Sengketa Konsumen Yang Ideal Dalam Rangka Meningkatkan Perlindungan Terhadap Konsumen

Oleh : Janus Sidabalok, S.H., M.Hum 
j. Putusan BPSK diminta penetapan eksekusinya ke PN,

k. Para pihak dapat mengajukan keberatan atas putusan BPSK,

1. Para pihak dapat mengajukan kasasi paling lama 14 hari kerja atas putusan $\mathrm{PN}$,

m. MA mengeluarkan putusan paling lama 30 hari kerja setalah menerima permohonan kasasi.

5. Acara Pemeriksaan Perkara pada

BPSK dan PN/ MA

Tahapan pemeriksaan perkara perdata di pengadilan negeri pada pokoknya terdiri dari: Pembacaan gugatan, Pembacaan Jawaban, Replik, Duplik, Pembuktian, Kesimpulan, dan Putusan. ${ }^{11}$

Sebelum gugatan dibacakan, penggugat terlebih dahulu mendaftarkan gugatannya ke pengadilan, lalu pengadilan nmenetapkan majelis hakim yang akan memeriksa perkara, menetapkan hari sidang, dan memanggil para pihak untuk hadir di persidangan.

Pada persidangan pertama, hakim terlebih dahulu mengusulkan agar para pihak mengusahakan perdamaian. Jika tidak tercapai kesepakatan, dilanjutkan dengan pembacaan gugatan. Jika para pihak masih membutuhkan waktu untuk berdamai, maka pada sidang ini pembacaan gugatan tidak dilakukan.

Atas gugatan penggugat, tergugat mengajukan jawaban, seterusnya replik (penggugat) dan duplik (tergugat).

Acara sidang kemudian dilanjutkan dengan pembuktian, melalui pemeriksanaan alat bukti yang diajukan oleh penggugat dan tergugat, yang mungkin berlangssung dalam beberapa kali sidang. Setelah acara pembuktian selesai, dilanjutkan dengan pengajuan kesimpulan, dan sebagai penutup,

11 Bdk. Djamanat Samosir, Hukum Acara Perdata, Bandung: Nuansa Aulia, 2011, hlm.157-158. hakim membacakan putusan yang dilakukan pada sidang tersendiri.

Tahapan-tahapan di atas adalah tahapan sederhana, dengan kemungkinan acara persidangan akan lebih panjang lagi apabila ada pihak ketiga yang masuk ke dalam perkara tersebut (intervensi). Menurut Keputusan Menteri Perindustrian dan Perdagangan Nomor 350/MPP/ Kep/12/ 2001 tentang Pelaksanaan Tugas dan Wewenang BPSK, berperkara di BPSK dilakukan dengan tahapan-tahapan sebagai berikut: Memasukkan permohonan, Pemeriksaan administratif, Pemanggilan, Sidang pemeriksaan, Putusan (atau perjanjian).

6.Ketentuan undang-undang mengenai Kompetensi BPSK

UUPK tidak menyebut secara spesifik sengketa atau perkara yang menjadi kompetensi BPSK. Oleh karena itu terbuka kemungkinan perbedaan pandangan antara konsumen dengan pelaku usaha, serta antara BPSK dengan pengadilan.

Dengan demikian sengketa konsumen yang menjadi kompetensi BPSK adalah sengketa konsumen yang diajukan oleh seorang konsumen atau ahli warisnya, yang berisi tuntutan ganti ruugi karena kerusakan, pencemaran, atau karena timbulnya kerugian konsumen akibat mengonsumsi barang dan atau jasa; serta tuntutan ganti rugi akibat ketidaktersediaan suku cadang dan akibat tidak dipenuhinya jaminan atau garansi.

Akan tetapi menurut Pasal 46 ayat (2) UUPK gugatan yang diajukan oleh sekelompok konsumen, lembaga perlindungan konsumen swadaya masyarakat atau pemerintah diajukan kepada peradilan umum. Ini berarti bahwa BPSK tidak berkompeten atas sengketa konsumen ini.

Mencari Sistem Penyelesaian Sengketa Konsumen Yang Ideal Dalam Rangka Meningkatkan Perlindungan Terhadap Konsumen

Oleh : Janus Sidabalok, S.H., M.Hum 


\section{PEMBAHASAN}

1. Tentang Hubungan antara Pelaku Usaha dengan Konsumen, serta Tanggung jawab Pelaku Usaha

Sehubungan dengan perlindungan konsumen, UUPK merumuskan sejumlah hak dan kewajiban konsumen yang bertimbal balik dengan hak dan kewajiban konsumen. Hal ini dapat dimaknai sebagai upaya menciptakan hubungan yang seimbang dan serasi antara pelaku usaha dengan konsumen. Hal ini juga menegaskan bahwa antara pelaku usaha dan konsumen mempunyai kedudukan seimbang dan saling membutuhkan.

Dalam pandangan UUPK, pelaku usaha mempunyai kewajiban menciptakan iklim berusaha serta iklim ekonomi yang sehat serta ikut bertanggungjawab dalam pembangunan ekonomi secara umum. Kewajiban ini harus dimenuhi dengan secara baik dan penuh tanggung jawab. Pelaku usaha bertanggungjawab secara hukum atas segala akibat kesalahannya dalam menjalankan kewajiban-kewajiban itu. Pelaku usaha juga dapat dituntut secara hukum atas setiap kesalahannya dalam menjalankan kewajiban-kewajiban itu.

Pelaku usaha mempunyai tanggung jawab sekurang-kurangnya dalam dua aspek, yaitu:

1. menciptakan iklim berusaha yang sehat, baik antara sesama pelaku usaha maupun antara pelaku usaha dengan masyarakat konsumen.

2. melindungi masyarakat konsumen, dari kemungkinan timbulnya kerugian terhadap diri konsumen maupun harta bendanya.

Dengan demikian mengusahakan kesejahteraan rakyat melalui penyediaan kebutuhan yang baik, sehat, dan berkualitas juga merupakan tanggung jawab produsen sebagai pelaku usaha.

Selain tanggung jawab publik itu, pelaku usaha juga memunyai tanggung jawab privat, tanggung jawab sehubungan dengan transaksi konsumen, dan tanggung jawab berdasarkan hubungan hukum yanglahir kemudian, sebagai konsekuensi dari memakai atau mengonsumsi produk. Dengan kata lain pelaku usaha bertanggungjawab atas dasar wanprestasi dan perbuatan melawan hukum. Apabila melalaikan tangung jawab itu, timbullah sengketa konsumen.

2. Tentang Penyelesaian Sengketa Konsumen

Mengikuti ketentuan Pasal 19 ayat (3) dan Pasal 23 jis Pasal 45 ayat (1) dan Pasal 47 UUPK, sengketa konsumen dapat diselesaikan di luar pengadilan dan melalui pengadilan.

Penyelesaian sengketa di luar pengadilan ialah penyelesaian melalui lembaga yang bertugas menyelesaikan sengketa antara konsumen dengan pelaku usaha, (yaitu BPSK), dan atau forum lain untuk mencapai kesepakatan.

Dengan demikian, terbuka tiga forum dan cara untuk menyelesaikan sengketa konsumen, yaitu: di luar pengadilan dengan tuntutan seketika; melalui BPSK dengan cara konsiliasi, mediasi, dan arbitrase; dan melalui pengadilan.

Penyebutan tentang ketiga forum ini kurang tegas di dalam UUPK. Mestinya disebutkaan dengan tegas bahwa sengketa konsumen daapat diselesaikan di luar pengadilan melalui negosiasi, mediasi, dan sebagainya, untuk membedakan penyelesaian melalui BPSK yang juga menggunakan cara negosiasi, konsiliasi, mediasi, dan arbitrase yang dilakukan BPSK.

Adalah lebih baik jika dirumuskan: sengketa konsumen dapat 
diselesaikan di luar pengadilan, melalui BPSK, dan melalui pengadilan. Satu dari ketiga forum dan cara itu dapat ditempuh oleh pihak-pihak yang bersengketa, dengan ketentuan bahwa penyelesaian sengketa di luar pengadilan melalui tuntutan seketika wajib ditempuh pertama kali untuk memperoleh kesepakatan para pihak.

Sedangkan dua forum dan cara lainnya adalah pilihan yang ditempuh setelah penyelesaian dengan cara kesepakatan gagal. Forum BPSK atau pengadilan dipilih secara sukarela sebagaimana dikemukakan pada Pasal 45 ayat (2) UUPK tersebut. Kalau sudah memilih untuk menempuh forum dan cara BPSK, penyelesaian melalui forum dan cara pengadilan tidak dapat lagi ditempuh sebagaimana ditentukan pada Pasal 45 ayat (4) UUPK.

Demikian halnya bahwa sengketa konsumen tidak dapat diajukan ke pengadilan dan di luar pengadilan sekaligus, misalnya salah satu pihak mengajukan gunatan ke BPSK dan juga ke pengadilan; atau pihak yang satu mengajukan ke BPSK sementara pihak lain mengajukan ke pengadilan. Ketentuan ini pun mesti tegas disebutkan di dalam UUPK.

Menurut Pasal 46 ayat (1) UUPK pihak-pihak yang berkepentingan dalam sengketa konsumen adalah:

a. seorang konsumen yang dirugikan atau ahli waris yang bersangkutan;

b. kelompok konsumen yang mempunyai kepentingan yang sama;

c. lembaga perlindungan konsumen swadaya masyarakat yang memenuhi syarat,

d. pemerintah dan/ atau instansi terkait.

Dengan ketentuan bahwa gugatan yang diajukan oleh sekelompok konsumen, lembaga perlindungan konsumen swadaya masyarakat atau pemerintah diajukan kepada peradilan umum. Ini berarti gugatan di luar pengadilan hanya dapat diajukan oleh seorang konsumen atau ahli warisnya. Menurut penulis, sekelompok konsumen dan lembaga swadaya masyarakat perlindungan konsumenpun mesti diberi peluang mengajukan gugatan ke BPSK.

Persoalan yang tersisa dari ketentuan UUPK ini adalah bagaimana dengan gugatan dari pelaku usaha? Apakah pelaku usaha tidak diberi hak menggugat konsumen, sedangkan pelaku usaha juga mempunyai hak untuk dilindungi dari kemungkinan kerugian yang timbul akibat kealahan konsumen? Hal ini tidak diatur dengan tegas di dalam UUPK dan menjadi salah satu kelemahan dari undang-undang tersebut. Bukankah UUPK antara lain bertujuan menjalin hubungan yang serasi antara konsumen dengan pelaku usaha?

Mengikuti ketentuan Pasal 48 UUPK, menurut Pasal 142 RBG/118 HIR, tuntutan atau gugatan itu harus diajukan dalam bentuk surat gugatan, yang ditandatangani oleh penggugat atau kuasanya kepada Ketua Pengadilan Negeri yang dalam daerah hukumnya terletak tempat tinggal tergugat atau jika tidak diketahui tempat tinggalnya, tempat tinggalnya tergugat sebenarnya berdiam (ayat (1).

Jika tergugat lebih dari seorang, sedangkan mereka tinggal dalam suatu daerah hukum pengadilan negeri, gugatan diajukan kepada ketua pengadilan negeri tempat tinggal salah seorang tergugat menurut pilihan penggugat (ayat (2). Jika tempat tinggal tergugat tidak diketahui, begitu pula sebenarnya dia berdiam tidak diketahui atau kalau dia tidak dikenal, gugatan itu diajukan kepada ketua pengadilan 
negeri tempat tinggal penggugat atau salah seorang penggugat (ayat (3).

Dalam sengketa konsumen, pihakpihak yang digugat adalah produsenpelaku usaha, yaitu semua pihak yang ikut serta di dalam penyediaan dan peredaran produk hingga sampai ke tangan konsumen. Jadi, sangat mungkin terdiri dari beberapa orang (pihak) yang berbeda. Dalam hal seperti ini jika tergugat ada beberapa orang, dapat dipilih di tempat tinggal salah satu tergugat sebagai tempat mengajukan gugatan.

Pada umumnya gugatan itu diajukan secara tertulis. Namun demikian gugatan dapat diajukan secara lisan. Dalam gugatan, dikemukakan dalil yang berupa dasar tuntutan yang disebut pundamentum petendi ${ }^{12}$, terdiri dari bagian yang menguraikan kejadian atau peristiwa dan bagian yang menguraikan tentang hukum. Ada dua peristiwa yang dapat diajukan sebagai dasar hak konsumen untuk mengajukan tuntutan, yaitu peristiwa wanprestasi dan perbuatan melawan hukum sebagaimana telaah dipaparkan di atas.

Pada bagian akhir gugatan dimuat petitum $^{13}$, yaitu tuntutan apa yang oleh penggugat diminta atau diharapkan akan diputuskan oleh hakim. Jadi petitum itu akan mendapatkan jawabannya di dalam dictum atau amar putusan.

Sebagaimana disebutkan dalam Pasal 1865 KUH Perdata, peristiwa yang menjadi dasar hak itu harus dibuktikan oleh penggugat. Artinya, kalau gugatan atas ganti kerugian didasarkan pada peristiwa wanprestasi, penggugat perlu membuktikan:

1) adanya hubungan perikatan (kontrak, perjanjian);

12 Sudikno Mertokusumo, 1988, Hukum Acara Perdata Indonesia, Penerbit Liberty, Yogyakarta, hlm. 35.

13 Ibid, hlm. 36.
2) adanya bagian-bagian dari kewajiban yang tidak dipenuhi oleh pelaku usaha; dan

3) timbulnya kerugian bagi konsumen-penggugat.

Jika gugatan ganti kerugian didasarkan pada peristiwa perbuatan melawan hukum, haruslah dibuktikan:

a. adanya perbuatan melawan hukum, baik berupa pelanggaran hak konsumen, pelanggaran terhadap kewajiban berhati-hati, pelanggaran norma kesusilaan, maupun pelanggaran norma kepatutan.

b. adanya kesalahan dari pelaku usaha, baik berupa kesengajaan maupun kelalaian.

c. adanya sejumlah kerugian yang diderita konsumen-penggugat.

d. adanya hubungan kausal antara perbuatan melawan hukum yang salah itu dan kerugian.

Kemudian dibuktikan dengan alat bukti surat, saksi, persangkaan, pengakuan dan sumpah, sebagaimana diatur pada Pasal 284 RBG/164 HIR atau Pasal 1866 KUH Perdata.

3.Tugas dan Wewenang, serta Kompetensi BPSK

Mencermati rumusan tugas dan wewenang BSK sebagaimana diatur pada Pasal 52 UUPK dapat dikatakan bahwa BPSK adalah lembaga yang tambun, selain sebagai lembaga peradilan kuasi, juga berperan sebagai lembaga pemberi pendapat, melayani permintaan konsultasi, lembaga pengawas, dan sebagainya.

Sebaiknya tugas-tugas lain selain dari penyelesaian sengketa tidak diberikan kepada BPSK, sehingga BPSK murni sebagai lembaga penyelesaian sengketa di luar pengadilan. ${ }^{14}$ Barang kali karena rumusan tugas dan wewenang seperti

14 Janus Sidabalok, Hukum Perlindungan.... Op

Mencari Sistem Penyelesaian Sengketa Konsumen Yang Ideal Dalam Rangka Meningkatkan Perlindungan Terhadap Konsumen

Oleh : Janus Sidabalok, S.H., M.Hum 
tertera pada Pasal 52 UUPK itulah BPSK seolah-olah bagian dari eksekutif, berada di bawah Kemenperindag, pada hal seharusnya tidak demikian. BPSK mestinya berada di luar dari pemerintahan dan bersifat independen.

Penyelesaian sengketa konsumen yang ideal juga dipengaruhi oleh aturan tentang kompetensi BPSK berikut pemahaman semua pihak atas kompetensi itu.

Sengketa berupa tuntutan kerugian karena kerusakan dan pencemaraan dapat dikategorikan sebagai kerugian ekonomis (economic loose), sedangkan kerugian konsumen dapat dikategorikan sebagai physical harm, berupa sakit atau meninggal dunia. $^{15}$

Akan tetapi jika dihubungkan dengan ketentuan tentang tanggung jawab pelaku usaha lain sebagaimana dimaksud pada Pasal 20 dan Pasal 25 UUPK maka lingkup sengketa konsumen menjadi lebih luas lagi karena masuk di dalamnya sengekta yang timbul akibat dari iklan, akibat ketidaktersediaan suku cadang, dan akibat dari tidak dipenuhinya jaminan atau garansi.

BPSK cenderung mempunyai pemahaman bahwa semua sengketa yang berkaitan dengan konsumen adalah kompetensi BPSK. Mahkamah Agung (MA) pernah mempunyai pemahaman yang sama seperti BPSK tersebut. Namun sejak tahun 2013 MA mempunyai sikap konsisten dan menjadi yurisprudensi hingga kini, bahwa tidak semua sengketa yang melibatkan konsumen menjadi kompetensi BPSK, terutama sengketa yang timbul dari perjanjian pembiayaan dan kredit, baik dengan hak tanggungan

15 Ibid, hlm.140. mupun fidusia yang menurut MA adalah kompetensi peradilan umum. ${ }^{16}$

4. Tata kerja dan Eksekusi Putusan BPSK

Hal lain yang juga penting berkaitan dengan berperkara adalah eksekusi putusan, sebab dengan eksekusilah pihak yang dimenangkan di dalam perkara memperoleh haknya. Menurut Pasal 57 UUPK putusan BPSK dimintakan fiat eksekusinya ke Pengadilan Negeri. Ketentuan Pasal 57 UUPK tersebut diperjelas pada Pasal 42 Kepmenperindag

Nomor 350/MPP/Kep/12/ $2001 \quad$ yang menentukan bahwa pihak yang memohonkan eksekusi adalah BPSK. Ketentuan ini menimbulkan pertanyaan, mengapa BPSK bertindak sebagai pemohon eksekusi, bukankah semestinya pihak yang dimenangkan dalam putusan?

Purwoto S. Gandasubrata mengemukakan asas-asas hukum eksekusi yang harus diperhatikan dalam dalam pelaksanaan eksekusi sebagai beriukut:

1. Eksekusi dijalankan atas putusan pengadilan yang sudah berkekuatan hukum tetap, apabila tereksekusi tidak mau melaksanakan putusan secara suka rela, kecuali undang-undang menentukan lain;

2. Yang dapat dieksekusi adalah amar putusan yang bersifat penghukuman (condemnatoir), sedangkan putusan yang bersifat konstitutif atau declaratoir tidak memerlukan eksekusi;

3. Eksekusi dilakukan atas perintah daan di bawah pimpina Ketua Pengadilan Negeri yang bersangkutan, dilaksanakan oleh

16 MA RI, Yurisprudensi Mahkamah Agung Tahun 2018, Jakarta: Biro Hukum dan Humas Badan Urusan Administrasi MA, hlm. 28 .

Mencari Sistem Penyelesaian Sengketa Konsumen Yang Ideal Dalam Rangka Meningkatkan Perlindungan Terhadap Konsumen

Oleh : Janus Sidabalok, S.H., M.Hum 
Panitera dan juru sita dengan bantuan alat kekuasaan negara di mana diperlukan;

4. Ekekusi dilaksanakan menurut ketentuan peraturan perundangundangan yang berlaku, secara terbuka dan diusahakan peri kemanusiaan dan perikeadilan tetap terpelihara. ${ }^{17}$

Selain itu berkaitan dengan keberadaan BPSK sebagai lembaga alternatif pun mempunyai kelemahankelemahan dari sissi pengaturannnya. Kurniawan mencatat sejumlah kelemahan sebagai berikut:

a. Peluang untuk mengajukan keberatan terhadap putusan BPSK sangat besar.

b. Kurang jelas tugas dan kewenangan BPSK.

c. Tidak adanya pengaturan jika pelaku usaha selaku tergugat di BPSK tidak memenuhi panggilan meski telah dipanggil secara patut.

d. UUPK menugaskan BPSK untuk melakukan pengawasan pencantuman klausula baku.

e. Tidak adanya perlindungan bagi anggota BPSK.

f. Belum adanya keseragaman honor BPSK se-Indonesia yang diatur dalam APBN, sementara biaya operasional dibebankan pada APBD Kabupaten/ Kota. ${ }^{18}$

Oleh karena itu untuk menjadikan BPSK sebagai lembaga penyelesaian sengketa konsumen yang ideal, kelemahan di atas mesti dieliminir melalui peraturan perundang-undangan yang baru.

17 Kurniawan, Penyelesaian Sengketa Konsumen Melalui BPSK, dalam Jurnal Hukum dan Pembangunan, Tahun ke-41 No.3, Juli-September 2011, Jakarta: FH-UI, hlm.345.

18 Loc Cit.

\section{KESIMPULAN DAN SARAN}

1. KESIMPULAN

Berdasarkan pembahasan pada bagian yang lalu, dapat ditarik kesimpulan sebagai berikut:

1. Penyelesaian

Sengketa

Konsumen:

a. Ketentuan yang terdapat di dalam Undang-Undang Nomor 8 Tahun 1999 tentang Perlindungan Konsumen mengenai penyelesaian sengketa konsumen masih mengandung sejumlah kelemahan, baik karena tidak ada mengatur maupun karena pengaturan yang kurang jelas, sehingga memengaruhi konsumen memperolah haknya melalui penyelesaian sengketa konsumen.

b. Kelemahan itu antara lain tidak ada rumusan tentang sengketa konsumen, dan batasan mengenai sengketa konsumen yang dapat diselesaikan di luar pengadilan, dan melalui BPSK.

c. Sedangkan rumusan sengeta konsumen di dalam Kepmenperindag Nomor 350/ $\mathrm{MPP} / \mathrm{Kep} / 12 / 2001$ tidak mencakup semua tanggung jawab pelaku usaha.

2. Tentang organisasi, tugas dan wewenang, tata kerja, dan putusan BPSK.

a. Ketentuan tentang organisasi, tugas dan wewenang, tata kerja, dan putusan BPSK di dalam UUPK belum mampu melahirkan sebuah lembaga penyelesaian sengketa sebagai alternatif, antara lain karena rumusan tugas dan wewenang BPSK terlalu luas.

b. Peran BPSK yang juga menjadi bagian dari eksekutif turut memengaruhi efektivias

Mencari Sistem Penyelesaian Sengketa Konsumen Yang Ideal Dalam Rangka Meningkatkan Perlindungan Terhadap Konsumen

Oleh : Janus Sidabalok, S.H., M.Hum 
pelaksanaan tugas BPSK sebagai lembaga penyelesian sengketa.

c. Ketentuan undang-undang mengenai putusan BPSK menjadi bukti permulaan yang cukup untuk memproses kesalahan pelaku usaha secara pidana menjadi kontra produktif. Hal ini mengakibatkan adanya kecenderungan tergugat atau termohon untuk mengajukan keberatan atas putusan BPSK. Jika hal ini terjadi

d. maka unsur cepat dan murah tidak terpenuhi.

e. Sementara itu batasan tentang konsumen yang dapat mengajukan sengketa ke BPSK berpotensi mempersempit kesempatan konsumen untuk mengajukan sengketa ke BPSK dengan mengharuskannya ke peradilan umum.

\section{SARAN}

Untuk memperoleh penyelesaian sengketa konsumen yang ideal di kemudian hari disarankan sebagai berikut:

a. Agar undang-undang memberi rumusan tentang sengketa konsumen yang sama dengan halhal yang menjadi cakupan tanggung jawab pelaku usaha sebab menggugat pelaku usaha pada dasanya adalah menuntut pemenuhan tanggung jawab pelaku usaha.

b. Selanjutnya perlu rumusan yang tegas mengenai penyelesaian sengketa konsumen di luar pengadilan dan di luar BPSK yang bermaksud untuk memperoleh perdamaian di antara para pihak, baik langsung maupun dengan bantuan pihak ketiga. c. Rumusan tugas dan wewenang BPSK sebaiknya dipersempit hanya mencakup tugas dan wewenang BPSK sebagai badan penyelesaian sengketa konsumen. Bersamaan dengan itu BPSK hendaknya tidak ditempatkan sebagai bagian dari pemerintah, terutama dengan Kementerian Perdagangan (dahulu Kementerian Perindustrian dan Perdagangan).

d. Sementara itu perlu perluasan kesempatan bagi konsumen untuk memilih penyelesaian sengketa melalui BPSK, tidak hanya oleh seorang konsumen atau ahli warisnya, tetapi juga pahak lain.

e. Ketentuan undang-undang mengenai putusan BPSK menjadi bukti permulaan yang cukup untuk memproses kesalahan pelaku usaha secara pidana sebaiknya dihapus, sebab ketentuan ini cenderung mendorog pelaku uusaha untuk mengajukan kebertan atas putusan BPK. Menuntut pertanggungawaban pidana pelaku usaha sebaiknya dimulai dari proses awal tanpa mengaitkannya dengan proses perdata, dalam hal ini penyelesaiaan sengketa konsumen.

\section{DAFTAR PUSTAKA}

Fajar, M dan Achmad,Y, 2015, Dualisme Penelitin Hukum Normatif dan Empiris, Yogyakarta: Pustaka Pelajar.

Kurniawan, Penyelesaian Sengketa Konsumen Melalu BPSK, dalam Jurnal Hukum dan Pembangunan, Tahun ke-41 No.3, Juli-September 2011, Jakarta: FH-UI.

Mencari Sistem Penyelesaian Sengketa Konsumen Yang Ideal Dalam Rangka Meningkatkan 
Mahkamah Agung RI, 2019,Yurisprudensi Mahkamah Agung Tahun 2018, Jakarta: Biro Hukum dan Humas Badan Urusan Mahkamah Agung.

Marzuki, PM, 2014, Penelitian Hukum, Jakarta: Prenamedia Group.

Mertokusumo, Sudikno, 1988, Mengenal Hukum, Suatu Pengantar, Edisi Kedua Cetakan Pertama, Yogyakarta: Liberty.

---------, 1988, Hukum Acara Perdata Indonesia, Yogyakarta: Liberty.

Rasjidi, Lili dan Ida Bagus Wyasa Putra, 2012, Hukum Sebagai Suatu Sistem, Jakarta: Fikahati Aneska.

Samosir, Djamanat, 2011, Hukum Acara Perdata, Bandung: Nuansa Aulia.

Sibarani, Sinintha Y. Budaya Hukum Progresif Hakim Ad Hoc Penegakan Hukum Tindak Pidana Korupsi, dalam Dekonstruksi dan Gerakan Pemikiran Hukum Progresif, 2013, Moh. Mahfudz MD, dkk., Yogyakarta: Thafa Media- KHP Undip.

Sidabalok, Janus, 2014, Hukum Perlindungan Konsumen di Indonesia, Bandung: Citra Aditya Bakti.

--------, Beberapa Masalah Sekitar Efektivitas Badan Penyelesian Sengketa Konsumen (BPSK) yang Diatur di Dalam UU No.8 Tahun 1999 tentang Perlindungan Konsumen, Media Unika, majalah ilmiah Unika St.Thomas, Medan, Thn.17 No.55, Juli-Agustus 2005 ISSN.0852-1832.
Soekanto, Soerjono, 2012, Pengantar Penelitian Hukum, Jakarta: UI Press.

Suherman, Ade Maman, 2004, Pengantar Perbandingan Sistem Hukum, Jakarta: RajaGrafindo Persada.

Sutantio, Retnowulan dan Iskandar Oeripkartawinata, 2005, Hukum Acara Perdata dan Teori dan Praktek, Bandung: Mandar Maju. 